\title{
Self-assembly behavior of the keratose proteins extracted from oxidized Ovis aries wool fibers
}

\author{
Efecan Pakkaner ${ }^{1}$, Damla Yalçın, Berk Uysal, Ayben Top * \\ Department of Chemical Engineering, İzmir Institute of Technology, Urla, Izmir, Turkey
}

\section{A R T I C L E I N F O}

\section{Article history:}

Received 24 September 2018

Received in revised form 2 December 2018

Accepted 16 December 2018

Available online 17 December 2018

\section{Keywords:}

Wool keratose

Self-assembly

Hydrogel

\begin{abstract}
A B S T R A C T
Water soluble keratose proteins were obtained from an Ovis Aries wool using peracetic acid oxidation. The wool samples and the extracted keratose proteins were characterized by using FTIR, XRD, SEM and TGA techniques. Fractions of $\alpha$-keratose (MW $=43-53 \mathrm{kDa}$ ) along with protein species with molecular weights between $23 \mathrm{kDa}$ and $33 \mathrm{kDa}$ were identified in the SDS-PAGE analysis result of the extracted protein mixture. DLS and AFM experiments indicated that self-assembled globular nanoparticles with diameters between $15 \mathrm{~nm}$ and $100 \mathrm{~nm}$ formed at $5 \mathrm{mg} / \mathrm{ml}$ keratose concentration. On the other hand, upon incubation of $10 \mathrm{w}$ \% keratose solutions at $37^{\circ} \mathrm{C}$ and $50^{\circ} \mathrm{C}$, interconnected keratose hydrogels with respective storage modulus ( $G^{\prime}$ ) values of $0.17 \pm$ $0.03 \mathrm{kPa}$ and $3.7 \pm 0.5 \mathrm{kPa}$ were obtained. It was shown that the keratose hydrogel prepared at $37^{\circ} \mathrm{C}$ supported L929 mouse fibroblast cell proliferation which suggested that these keratose hydrogels could be promising candidates in soft tissue engineering applications.
\end{abstract}

(C) 2018 Elsevier B.V. All rights reserved.

\section{Introduction}

Self-assembly of molecules from biological origin to form nanocomplex structures has been a popular research trend throughout the years due to successful adaptations of this 'bottom-up' approach to innovative biological and medical applications and other technologies [1-4]. Briefly, spontaneous association of these molecules creates supramolecular architectures that are thermodynamically and mechanically stable at desired conditions with the possibility of precise control of construction via changing the physical parameters, including temperature, $\mathrm{pH}$, ionic strength, light intensity, electric and magnetic fields $[1,5,6]$. Driven by non-covalent forces such as hydrogen bonding, hydrophobic attractions and van der Waals and electrostatic interactions, selfassembly of proteins and peptides facilitated the formation of a variety of nanostructures such as nanofibers, nanorods, nanotubes and nanoparticles [2,7-15]. Although numerous synthetic and natural polymers can undergo self-assembly process, polymers from natural origin have gained a wider attraction as biomaterials due to their biocompatibility, significantly low cytotoxicity and biomolecular recognition abilities [6,16].

Keratin can be extracted from various body parts of birds, reptiles and mammalian species, including hair, wool, nails, horns, hooves and feathers. Thus, being the major by-product of the well-grown industries

\footnotetext{
* Corresponding author.

E-mail address: aybentop@iyte.edu.tr (A. Top).

1 Current address: Department of Chemical Engineering, University of Arkansas, Fayetteville, AR.
}

such as breeding, textile, wool and butchery, keratin is one of the most abundant biopolymers $[5,17,18]$. Different from the other proteins, it contains quite high cysteine content (5-10 mol\%) that promotes its mechanical, chemical and thermal stability features due to the disulfide bonds present in their structures [19-21]. Like the other biopolymers from biological origins such as collagen, elastin and chitosan, keratin alone and mixed with other polymers have been also tested in various biomedical applications such as delivery of bioactive agents [22-24], wound healing [17,25-27], and bone tissue engineering [28-30]. It has been almost genuinely proven that keratins are promising candidates as sustainable biomaterials due to their abundance, low cost and biocompatibility.

Among the available sources of keratin, wool keratins have received more interest than the keratins from the other body parts such as horn and hoof due to their higher extraction yields and structural advantages such as hygroscopicity. Additionally, it was reported that wool keratin has cell attachment domains such as arginine-glycine-aspartic acid (RGD) and leucine-aspartic acid-valine (LDV) groups in its amino acid sequence, which can also be contained in many extracellular matrix proteins like fibronectin [21,31]. Unsurprisingly, wool keratin film provided better attachment platform for fibroblasts compared to collagen film [32], and wool keratin derived sponges have been demonstrated to be suitable for long-term cell cultivation [21].

Although biomaterials based on keratins have been shown to be quite promising, one major concern that limits their application spectrum can be their poor solubility in aqueous medium due to the disulfide bridges that form easily by simple air oxidation of extracted keratin proteins. One of the methods to obtain soluble proteins from 


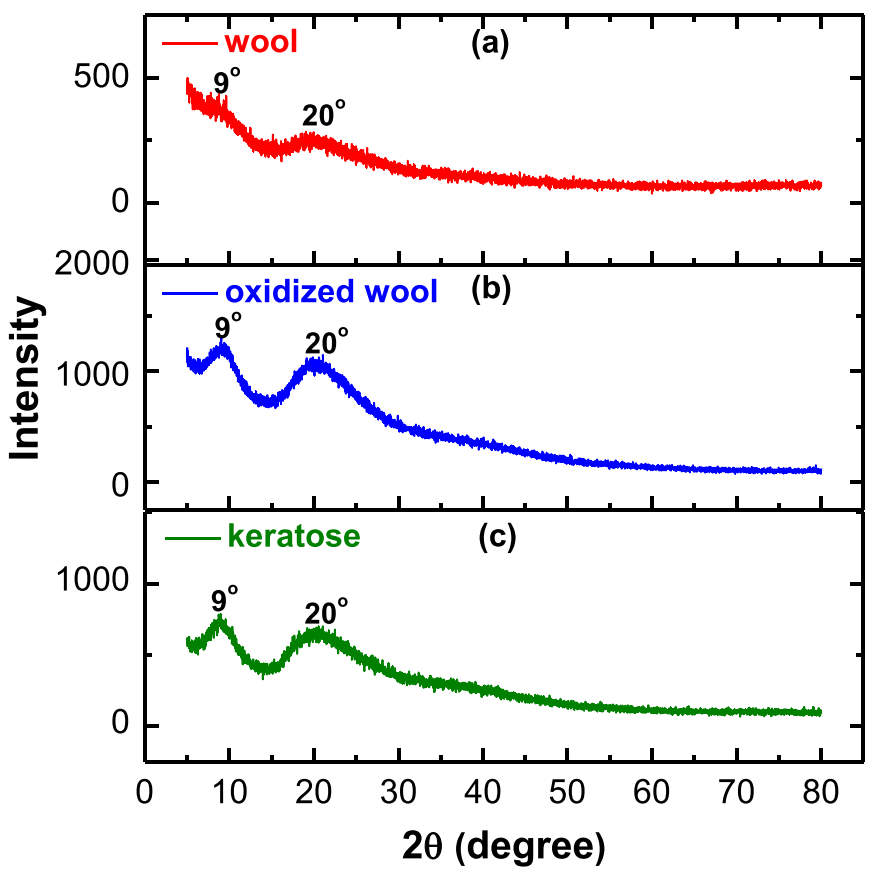

Fig. 1. XRD patterns of (a) the defatted wool, (b) the oxidized wool, and (c) the keratose.

keratins is the oxidative extraction, which gives keratoses via breaking of disulfide bonds and converting thiol groups of cysteines to cysteic acids. Recently, it has been shown that photo-crosslinked hydrogels from Merino wool keratose could form at 7.5 or $10 \mathrm{w} \%$ keratose concentrations [31]. Self-assembled hydrogels of the keratoses (at $15 \mathrm{w} \%$ concentration) from human hair have also been prepared [33,34]. In this study, we showed that physical hydrogels based on keratose proteins could also form at $10 \mathrm{w} \%$ concentration if another keratose source, wool from Akkaraman sheep breed, was used. Morphological, rheological and in vitro cell proliferation properties of these self-assembled hydrogels were evaluated. Size and morphology of self-assembled nanostructures of the keratose obtained at low concentration regime $(5-10 \mathrm{mg} / \mathrm{ml})$ were also investigated. Additionally, structural and thermal characterizations of the wool, the oxidized wool and the keratose extracted from the oxidized wool were performed.

\section{Experimental}

\subsection{Materials}

Wool samples from Akkaraman sheep breed (Ovis aries Linnaeus, 1758) localized in the Central Anatolian region of Turkey were kindly provided by Lalahan Livestock Central Research Institute (Ankara, Turkey) [35]. Acetic acid, chloroform, ethanol, hydrochloric acid $(\mathrm{HCl})$, L-glutamine, 2-( $\mathrm{N}$-morpholino)ethanesulfonic acid (MES), sodium dodecyl sulfate (SDS) and tris-base were purchased from Merck (Darmstadt, Germany). Methanol, tris- $\mathrm{HCl}$, peracetic acid solution (32 w \% in dilute acetic acid), sodium chloride, sodium hydroxide, sodium phosphate monobasic, Fourier transform infrared (FTIR) spectroscopy grade potassium bromide $(\mathrm{KBr})$, TruPAGE $®$ precast gels $(10 \times 8 \mathrm{~cm}$ with $4-12 \%$ gradient), cellulose membrane dialysis tubing (43 $\times 27 \mathrm{~mm}$, MWCO 14,000 Da), and CCK-8 cell counting kit were obtained from Sigma-Aldrich (Sigma-Aldrich Co., St. Louis, MO, USA). High glucose DMEM cell culture medium, European grade fetal bovine serum (FBS), trypsin-EDTA $0.25 \%$ solution, trypan blue solution $(5 \mathrm{mg} / \mathrm{ml})$, and gentamycin sulfate solution $(50 \mathrm{mg} / \mathrm{ml})$ from Biological Industries (Cromwell, CT, USA) were used in the cell proliferation experiments. Coomassie brilliant blue R-250 and PageRulerTM pre- stained protein ladder were purchased from Thermo Fisher Scientific (Waltham, MA, USA). All reagents were used without any purification.

\subsection{Keratose extraction}

The wool samples were intensively washed with deionized water to remove contaminants. Approximately, $5 \mathrm{~g}$ wool was contacted with $500 \mathrm{ml}$ deionized water and was shaken at $50{ }^{\circ} \mathrm{C}$, and at $150 \mathrm{rpm}$ for a few hours. The procedure was repeated until a clean solution was obtained. The cleaned wool was defatted using Soxhlet extraction with a solvent mixture containing chloroform and methanol (79:21 by volume) at its azeotropic temperature. For $5 \mathrm{~g}$ sample, $250 \mathrm{ml}$ solvent was used and the extraction process was proceeded at least $6 \mathrm{~h}$. Residual solvent in the defatted samples was evaporated at room temperature in a fume hood briefly, and removed by using a vacuum oven at $40^{\circ} \mathrm{C}$. Oxidation of the cysteines of the wool was performed by shaking $5 \mathrm{~g}$ dried fibers in $400 \mathrm{ml}$ peracetic acid solution $(2 \% \mathrm{w} / \mathrm{v})$ at $37^{\circ} \mathrm{C}$ and at $150 \mathrm{rpm}$ overnight by avoiding exposure to the light. The solution was separated with a ceramic filter and the oxidized fibers saved were washed thoroughly by using copious amount of deionized water. To extract soluble proteins, the oxidized fibers were treated with $200 \mathrm{ml}$ $100 \mathrm{mM}$ tris-base solution at pH 10.5 in an incubator at $37^{\circ} \mathrm{C}$ with a shaking rate of $150 \mathrm{rpm}$ for $3 \mathrm{~h}$ and the solution was filtered. This step was repeated two more times. The extraction solutions were combined and $\mathrm{pH}$ of the resultant solution was adjusted to $\sim 4$ using $1 \mathrm{~N} \mathrm{HCl}$ solution. The precipitated proteins were isolated by centrifugation, washed three times with $100 \mathrm{ml} 100 \mathrm{mM}$ tris- $\mathrm{HCl}$ buffer at $\mathrm{pH} 4.2$ and dissolved in $30 \mathrm{ml}$ tris-base solution at $\mathrm{pH} 10.5$. The protein solution was dialyzed against $4 \mathrm{~L}$ deionized water using a pretreated dialysis membrane tubing. Dialysis medium was changed thrice a day, and the dialysis process was carried out for 3 days. Finally, the dialyzed proteins were lyophilized and stored at $-20{ }^{\circ} \mathrm{C}$ (Yield $=35 \pm 5 \%$ ).

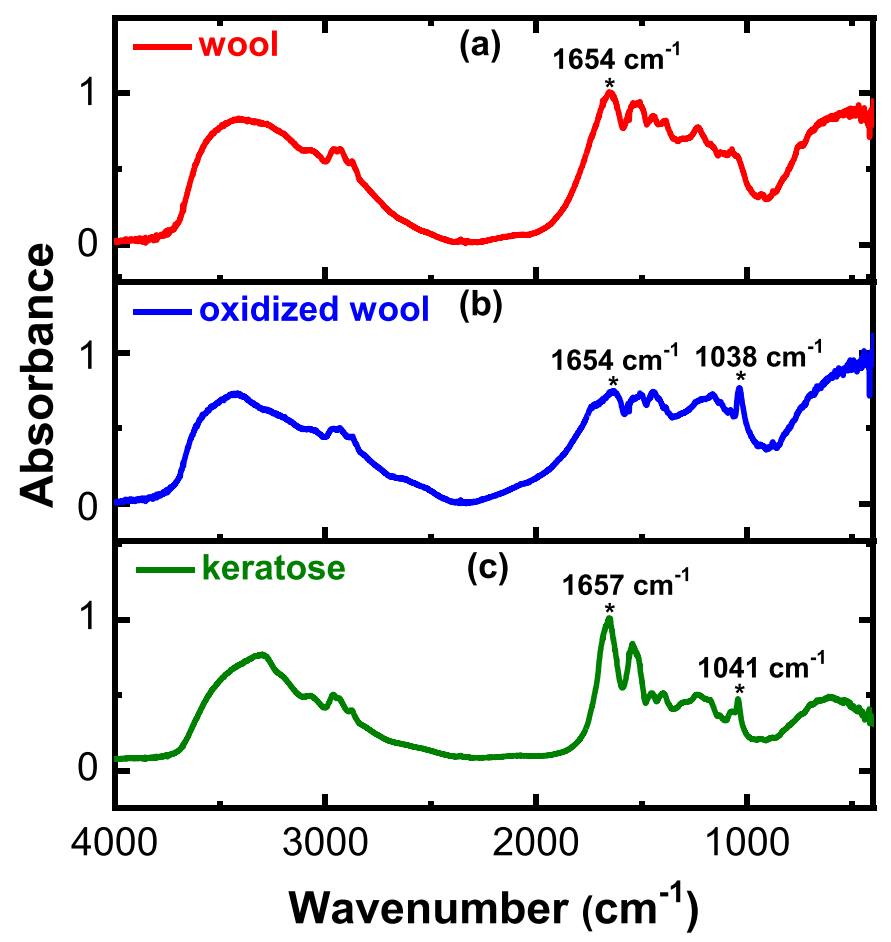

Fig. 2. FTIR spectra of (a) the defatted wool, (b) the oxidized wool, and (c) the keratose. 


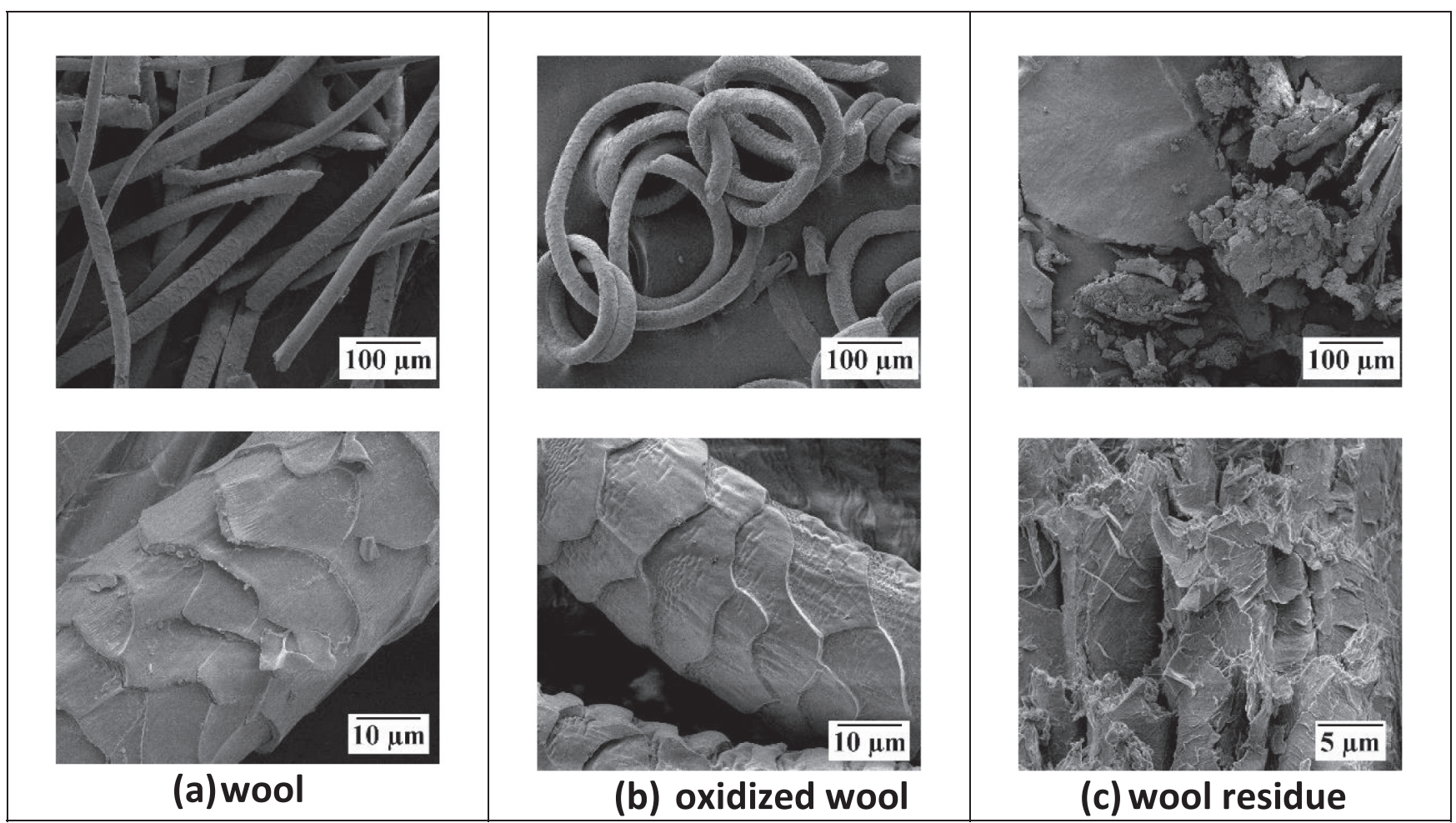

Fig. 3. SEM images of (a) the defatted wool, (b) the oxidized wool, and (c) the wool residue after the extraction.

2.3. Characterization of the wools and the keratose extracted from the oxidized wool

X-ray diffraction (XRD) analyses were carried out using a Philips PANalytical X'Pert Pro (Almelo, Netherlands) model diffractometer with an incident $\mathrm{CuK}_{\alpha}$ radiation at $1.54 \AA$ and a scan rate of 0.139 degree $/ \mathrm{min}$. The Bragg angles $(2 \theta)$ were changed between $5^{\circ}$ and $80^{\circ}$. FTIR spectroscopy of the samples was performed on a Shimadzu
$8400 \mathrm{~S}$ (Tokyo, Japan) spectrophotometer using $\mathrm{KBr}$ pellet technique. The spectra were taken between $400 \mathrm{~cm}^{-1}$ and $4000 \mathrm{~cm}^{-1}$ wavenumber range with a scan number of 32 and a resolution of $2 \mathrm{~cm}^{-1}$. To obtain the composition of secondary structure of the keratose, amide I region of its FTIR spectrum was deconvoluted into optimum number of Gaussian peaks according to $\mathrm{R}^{2}$ and $\chi^{2}$ values using Origin data analysis and graphing software (OriginLab, Northampton, MA). Scanning electron microscopy (SEM) images of the raw wool and the processed
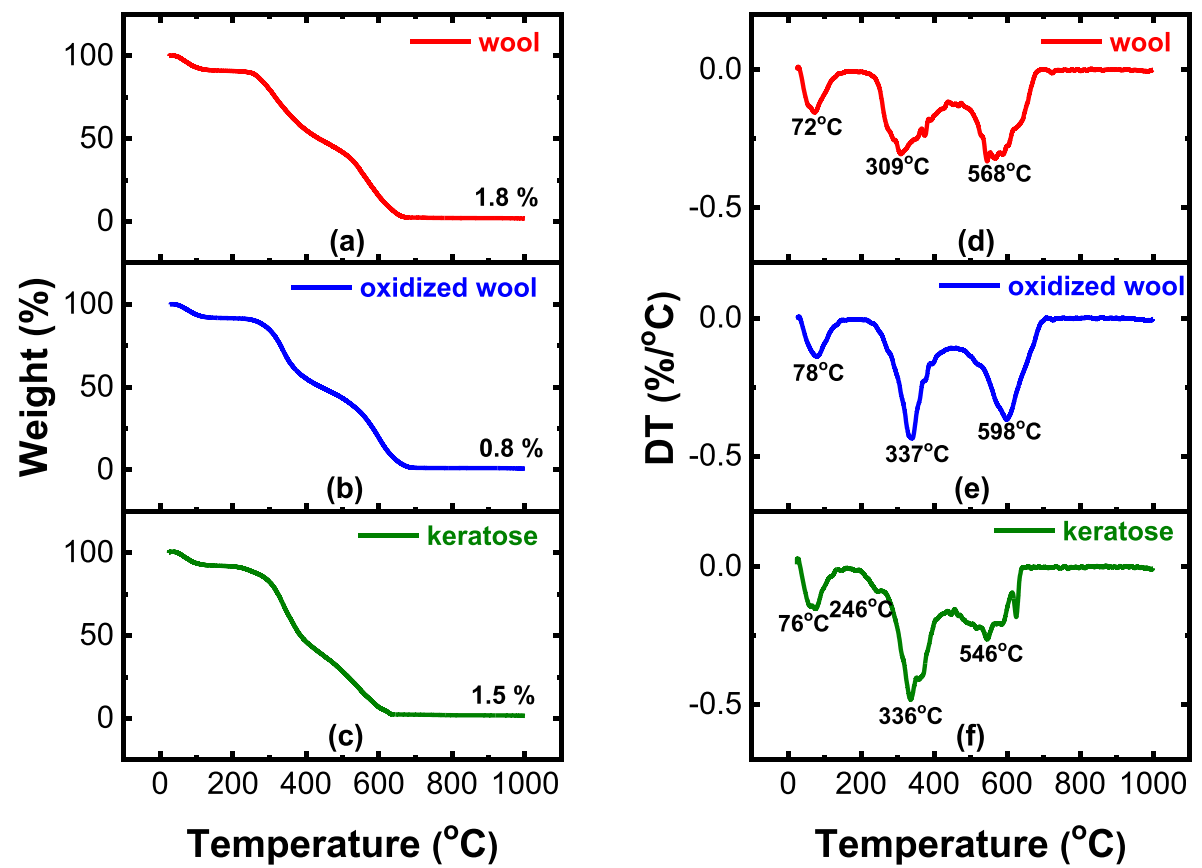

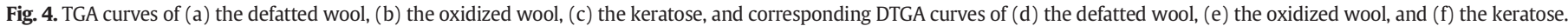


wools were observed using an FEI Quanta 250 FEG (Oregon, USA) model instrument. The samples were cut into fragments in millimeter size range and sputter-coated with gold layer in rarefied argon. Mean diameter of the raw wool fibers was determined using Image J software $(\mathrm{NIH}$, US), [36] by averaging the data from 20 different fibers. Thermal gravimetric analyses (TGA) of the raw wool, the oxidized wool and the keratose were conducted on a Shimadzu TGA-50 (Tokyo, Japan) model instrument between room temperature and $1000{ }^{\circ} \mathrm{C}$. TGA experiments were performed using $10^{\circ} \mathrm{C} / \mathrm{min}$ heating rate and nitrogen atmosphere with a flowrate of $40 \mathrm{ml} / \mathrm{min}$. Sodium dodecyl sulfate polyacrylamide gel electrophoresis (SDS-PAGE) was carried out using a TruPage ${ }^{\mathrm{TM}}$ precast gel with a gradient of $4-12 \%$. Keratose solution at $10 \mathrm{mg} / \mathrm{ml}$ concentration in the sample buffer was incubated at $90{ }^{\circ} \mathrm{C}$ for $5 \mathrm{~min} .2 \mu \mathrm{l}$ of denaturated protein solution was diluted with $8 \mu$ sample buffer and the mixture was loaded and run through the gel using a buffer with a composition of $1.2 \mathrm{M}$ tris-base, $0.6 \mathrm{M}$ MES and 2.0\% w/v SDS by applying a voltage of $180 \mathrm{~V}$ for $30 \mathrm{~min}$. Then, the gel was stained with Coomassie brilliant blue R-250 solution for $2 \mathrm{~h}$ and destained with a solution containing 20\% ethanol and 5\% acetic acid for $3 \mathrm{~h}$ with successive washes.

\subsection{Characterization of self-assembled keratose structures}

Keratose structures formed at low concentrations were characterized using dynamic light scattering (DLS) and atomic force microscopy (AFM) techniques. The protein solutions were prepared at 5 and $10 \mathrm{mg} / \mathrm{ml}$ concentrations using phosphate buffer saline (PBS; $10 \mathrm{mM}$ phosphate containing $150 \mathrm{mM} \mathrm{NaCl}$ at $\mathrm{pH} \mathrm{7.4)}$ and filtered. The solutions were equilibrated at $25^{\circ} \mathrm{C}$ for at least $15 \mathrm{~min}$ prior to DLS measurements recorded using a Micromeritics NanoPlus model instrument with three measurements for each sample. The size distributions of the samples were obtained using CONTIN method. $5 \mathrm{mg} / \mathrm{ml}$ keratose solution in deionized water was used in AFM characterization. $3 \mu \mathrm{l}$ of filtered solution was applied to freshly cleaved mica evenly and diluted with $10 \mu \mathrm{l}$ of Milli-Q grade water. AFM imaging was performed at room temperature, using tapping mode with a Bruker silicon cantilever tip having a spring constant of $0.1 \mathrm{~N} / \mathrm{m}$ (Camarillo, CA, USA). AFM observations were performed using a Digital Instruments-MMSPM Nanoscope IV model instrument and the data were analyzed using NanoScope Analysis software (Bruker, US).

To prepare hydrogels, the keratose proteins were dissolved in an appropriate solvent (PBS at pH 7.4 or deionized water) at $10 \mathrm{w} \%$ concentration. Resultant viscous solutions were incubated at $37^{\circ} \mathrm{C}$ or $50{ }^{\circ} \mathrm{C}$ for $4 \mathrm{~h}$ to promote gelation. Oscillatory rheology experiments of the hydrogels were carried out on a Thermo Fisher Scientific HAAKE MARS Rheometer (Waltham, MA, USA) instrument equipped with a stainless steel parallel plate with a diameter of $35 \mathrm{~mm}$. The keratose hydrogel prepared in PBS buffer at pH 7.4 was applied to the plate and the gap distance between the plates was adjusted to $0.5 \mathrm{~mm}$ and light mineral oil was used to block the sides of the plates to suppress the possible evaporation of the material during the rheological tests. Strain sweep experiments were performed at $1 \mathrm{~Hz}$ and frequency range was set between 0.01 and $100 \mathrm{~Hz}$ for frequency sweep experiments. The data were taken at $25{ }^{\circ} \mathrm{C}$. Each test was carried out duplicate and average of the two experiments with corresponding standard deviation values was presented. Pore size and interconnectivity of the hydrogel networks were evaluated using an FEI Quanta 250 FEG SEM (Oregon, USA) model instrument. Self-assembled hydrogels prepared in deionized water were soaked into liquid nitrogen and freeze-dried. Images of the cross-sectionally fractured portion of the samples were observed without coating with gold. Average pore size of the hydrogels was determined by measuring 30 pores from different spots using ImageJ software.

Cell proliferation (CCK-8) assay was performed using L929 mouse fibroblast cell line based on sets of four independent hydrogel samples and control samples. The cells were cultivated in the DMEM medium containing $2 \mathrm{mM}$ glutamine, 10\% fetal bovine serum (FBS) and $50 \mu \mathrm{g} /$

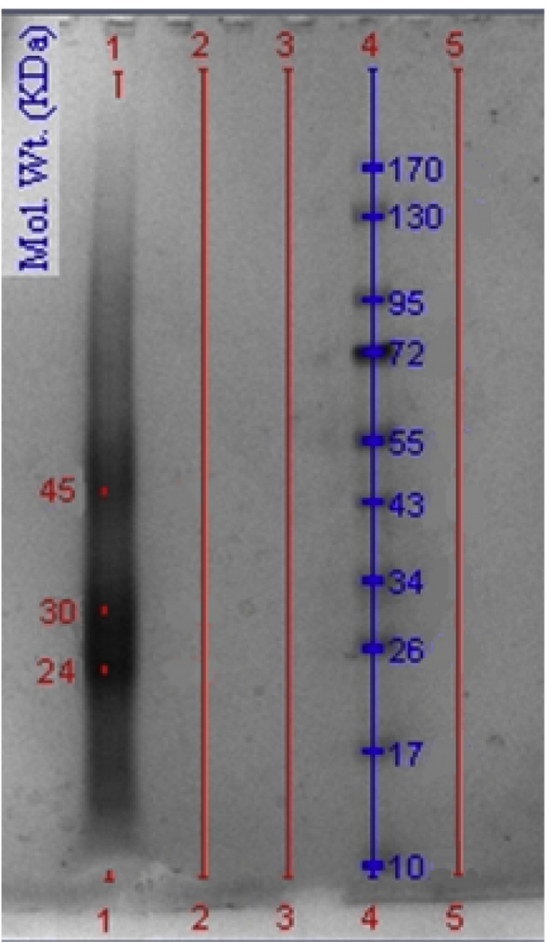

Fig. 5. SDS-PAGE patterns of the keratose. Samples: lane $1=$ keratose, lane $4=$ protein molecular weight marker.

$\mathrm{ml}$ gentamycin sulfate. $10 \mathrm{w}$ \% keratose solution was prepared in PBS buffer at $\mathrm{pH} 7.4$ and $100 \mu \mathrm{L}$ of the keratose solution was pipetted into each corresponding well of 96 well microplate and incubated at $37{ }^{\circ} \mathrm{C}$ to obtain the hydrogel. Empty tissue culture treated polystyrene (TCPS) wells were used for comparison. $100 \mu$ L929 cell solution (2.5 $\times 10^{4} \mathrm{cell} / \mathrm{ml}$ in cultivation medium) was added to each well and the microplates were incubated at $37{ }^{\circ} \mathrm{C}$ in $5 \% \mathrm{CO}_{2}$ atmosphere for 1 and 3 days. To determine cell proliferation, $10 \mu \mathrm{l} \mathrm{CCK}-8$ solution was added to each well and the microplates were incubated for $2 \mathrm{~h}$. Absorbance values at $450 \mathrm{~nm}\left(\mathrm{~A}_{450 \mathrm{~nm}}\right)$ were measured using Thermo Fisher Varioskan Flash microplate reader (Waltham, MA, USA). Relative cell

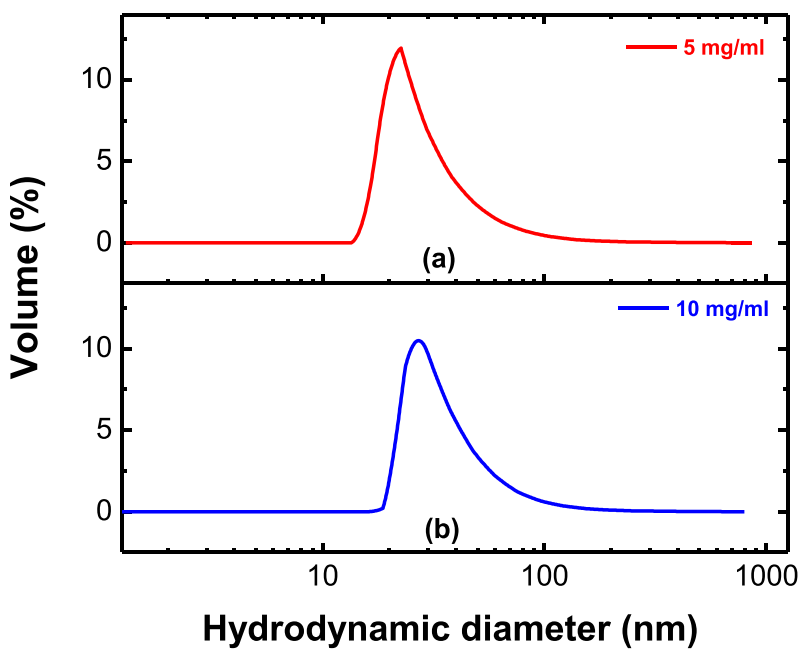

Fig. 6. Size distribution of the keratose solutions with concentrations of (a) $5 \mathrm{mg} / \mathrm{ml}$, and (b) $10 \mathrm{mg} / \mathrm{ml}$. 
Table 1

Summary of the DLS size distribution parameters.

\begin{tabular}{llllll}
\hline $\begin{array}{l}\text { Concentration } \\
(\mathrm{mg} / \mathrm{ml})\end{array}$ & $\begin{array}{l}\mathrm{D} 10 \\
(\mathrm{~nm})\end{array}$ & $\begin{array}{l}\mathrm{D} 50 \\
(\mathrm{~nm})\end{array}$ & $\begin{array}{l}\text { D90 } \\
(\mathrm{nm})\end{array}$ & $\begin{array}{l}\text { Peak max. } \\
(\mathrm{nm})\end{array}$ & PDI \\
\hline 5 & 18 & 24 & 50 & 23 & 0.507 \\
10 & 22 & 31 & 59 & 28 & 0.514 \\
\hline
\end{tabular}

proliferation rates of the samples were calculated using:

Relative cell proliferation rate

$\mathrm{A}_{450 \mathrm{~nm}}$ of the sample

$\mathrm{A}_{450 \mathrm{~nm}}$ of TCPS measured at the end of Day 1

Statistical analyses were carried out using independent two-sample t-test method on Minitab software (Minitab Inc., PA, US).

\section{Results and discussion}

\subsection{Characterization of the wools and the keratose}

XRD technique was used to detect crystallinity of the samples and changes in the ordered structures of the proteins during the extraction process. XRD curves of the defatted wool, the oxidized wool and the keratose are given in Fig. 1. The patterns composed of an amorphous background and broad peaks indicated that all the samples were semicrystalline. Additionally, the peak positions matched to those observed for $\alpha$-keratins [37]. The peaks were more apparent for the oxidized wool and the keratose samples suggesting their higher ordered structures content. Similarly, intensities of the XRD peaks were higher for the keratin extracted using L-cysteine at basic $\mathrm{pH}$ compared to those of the parent wool sample [38]. However, acid hydrolysis of a wool sample using $4 \mathrm{~N} \mathrm{HCl}$ at high temperature yielded amorphous structure [20]. The peak at $20^{\circ}$ corresponds to $\beta$-sheet structure whereas the other peak at $9^{\circ}$ represents both $\alpha$-helical and $\beta$-sheet conformations of the proteins $[38,39]$. No significant difference was observed between relative intensities of these two peaks for the oxidized wool and the keratose indicating that no detectable conformational changes occurred during the extraction of the keratoses from the oxidized wool. Thus, it is likely that the oxidation procedure applied in this study did not disrupt the ordered structures of the keratinous proteins, substantially.
Functional groups and structural changes occurred during the extraction of the proteins were determined using the FTIR spectra of the samples given in Fig. 2. Fingerprints of the proteinaceous structures were revealed by amide I (1600-1690 $\left.\mathrm{cm}^{-1}\right)$, amide II (1480-1575 $\left.\mathrm{cm}^{-1}\right)$, and amide $\mathrm{A}\left(\sim 3300 \mathrm{~cm}^{-1}\right)$ bands observed for all the wool samples and the keratose [40]. Additionally, formation of a new band observed for the oxidized wool and the keratose at about $1040 \mathrm{~cm}^{-1}$ was attributed to the asymmetric vibrations of S-O groups of the sulfonate in cysteic acid and confirmed the peracetic acid assisted oxidation of cysteines to cysteic acids [41,42]. However, in these spectra, symmetric vibrations of $\mathrm{S}-\mathrm{O}$ groups of the cysteic acid at $1075 \mathrm{~cm}^{-1}$ manifested as a weak band [41]. The sharp band observed at $1657 \mathrm{~cm}^{-1}$ in the spectrum of the keratose indicated that the extracted protein was rich in $\alpha$-helical secondary structure similar to the other $\alpha$ keratin family of proteins $[18,43,44]$. Amide I region of the FTIR spectrum of the keratose proteins in solid form was deconvoluted into Gaussian peaks and is given in Fig. S1 in Supporting Information section. Resulted fittings were analyzed for the compositions of the corresponding secondary structures of the keratose according to the suggested assignments [45]. Three Gaussian peaks at 1622, 1655, and $1689 \mathrm{~cm}^{-1}$ indicating respective $9 \% \beta$-sheet, $72 \% \alpha$-helix and $19 \% \beta$-turn content of the keratose were observed.

SEM pictures of the defatted and the oxidized wool and the residual material after the extraction of the keratose are given in Fig. 3a, b, and c, respectively. The defatted wool fibers were observed to be stiff and polydisperse with an average diameter of $29 \pm 10 \mu \mathrm{m}$. After the peracetic acid treatment, the oxidized fibers became more flexible and porous. Extraction of the keratoses, on the other hand, disrupted the fiber structures as clearly depicted from Fig. 3c. SEM images of the residual $\beta$-keratin rich structures obtained from another wool species indicated that those keratose proteins were not gently stripped from the wool fibers in consistent with the current study [42]. Interestingly, hair fibers subjected to the oxidation and the extraction processes were split longitudinally [46].

Thermal behavior of the defatted and the oxidized wool samples and the keratose was investigated using TGA and derivative thermal gravimetric analysis (DTGA) methods. The resultant curves are given in Fig. 4. All of the three samples exhibited three major thermal transitions by giving less than $2 \%$ residue at the end of $1000^{\circ} \mathrm{C}$. The first endotherm observed at $\sim 75 \pm 3{ }^{\circ} \mathrm{C}$ corresponded to removal of moisture and volatile materials which constitutes $\sim 6.5-7 \%$ of the total weight of the

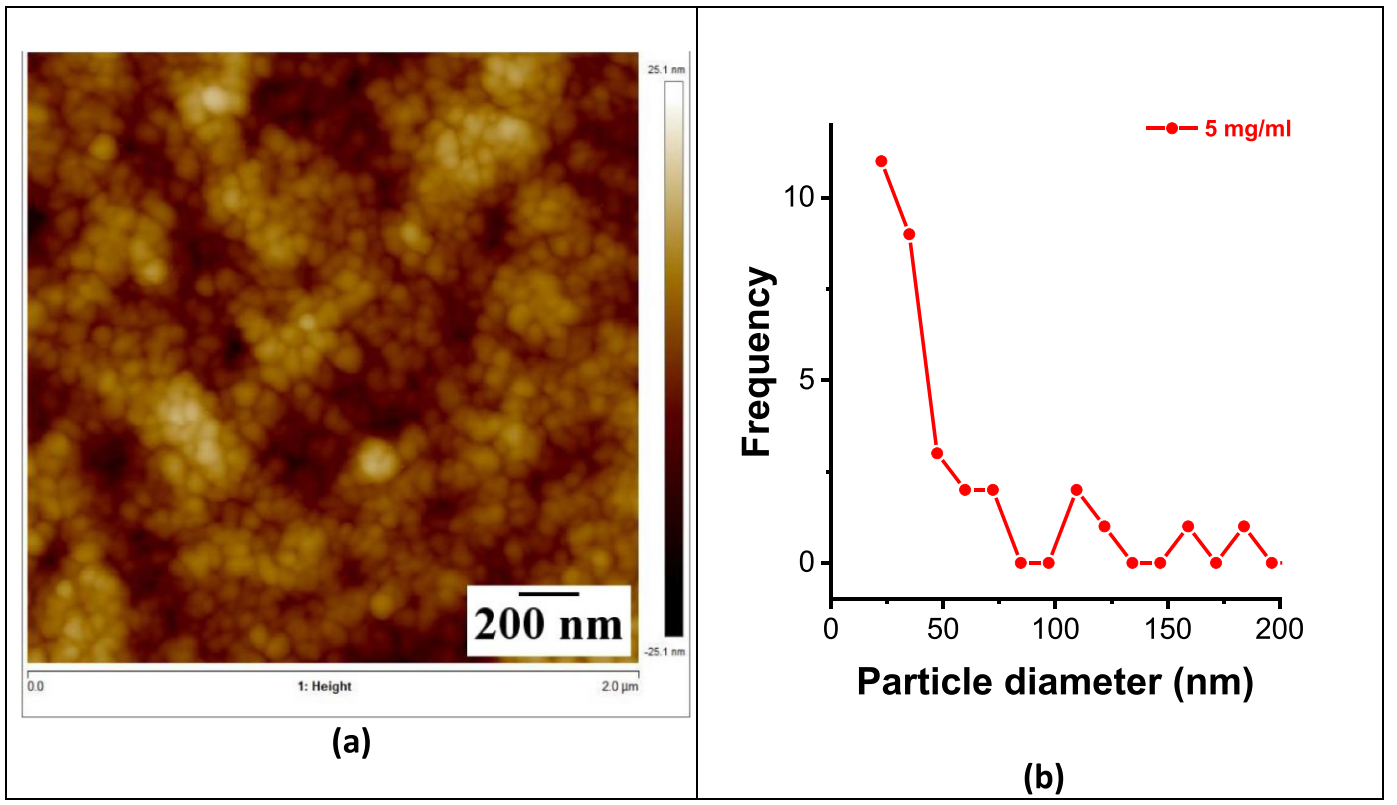

Fig. 7. (a) $2 \mathrm{D}$ AFM image, and (b) particle size distribution of the keratose prepared at $5 \mathrm{mg} / \mathrm{ml}$. 


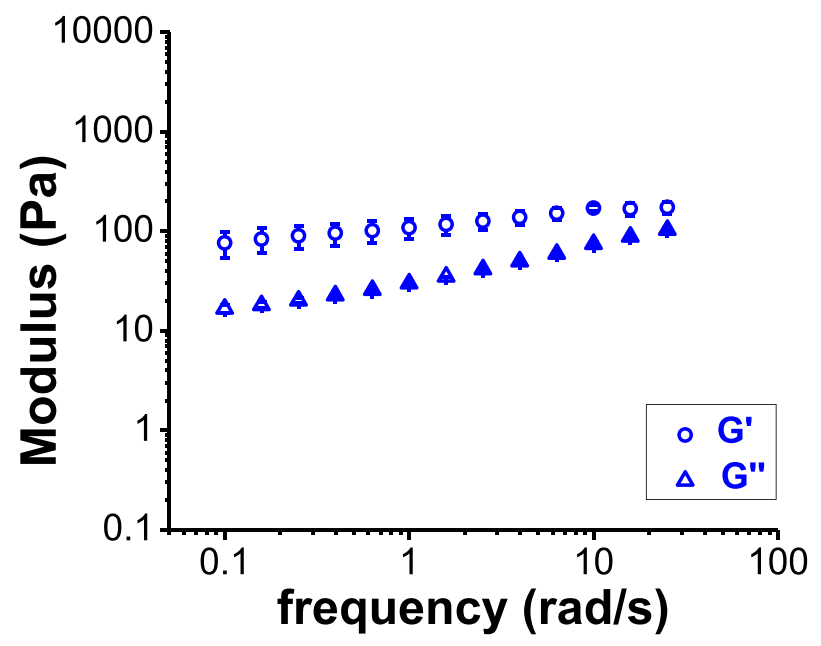

Fig. 8. Frequency sweep data of the hydrogel prepared at $37^{\circ} \mathrm{C}$.

samples. The second endotherm was obtained between $200{ }^{\circ} \mathrm{C}$ and 400 ${ }^{\circ} \mathrm{C}$ mainly indicating the degradation of the side chains of the proteins $[39,44,47]$. In this region, the corresponding weight losses were $36 \%$, $37 \%$, and $45 \%$ for the defatted wool, the oxidized wool and the keratose respectively. Similarly, $45 \%$ weight loss associated with the second endotherm was reported for keratin proteins from a bovine hoof [44]. Different from the wools, there appeared a shoulder at about $246^{\circ} \mathrm{C}$ within this second endotherm of the keratose which was probably due to the elimination of sulfur containing gases or other small molecules more cooperative manner. The last endotherm was observed between $450{ }^{\circ} \mathrm{C}$ and $600{ }^{\circ} \mathrm{C}$ and could be attributed to pyrolytic decomposition as suggested based on a sudden contraction in a dynamic mechanical analysis curve due to cyclization reactions [47].

SDS-PAGE data of the extracted keratoses are given in Fig. 5 and indicated a number of protein fractions populated between $14 \mathrm{kDa}$ and $100 \mathrm{kDa}$ in a diffusive manner rather than appearing as discrete bands. Relatively intense band between $\sim 43 \mathrm{kDa}$ and $\sim 53 \mathrm{kDa}$ matched to the molecular weight distribution of monomeric $\alpha$-keratose fractions extracted from an oxidized merino wool identified using LC-MS/MS [31]. The more distinct bands were observed between $\sim 23 \mathrm{kDa}$ and $\sim 33 \mathrm{kDa}$. It was reported that wool fibers also contained $\gamma$-keratin with high sulfur content and high tyrosine proteins in addition to $\alpha$ keratins (low sulfur proteins). For merino wool, molecular weight of $\gamma$-keratin was determined as $10.4 \mathrm{kDa}$ and no traces of tyrosine rich proteins were reported upon following similar oxidation process applied in current study [31]. Therefore, the bands between $23 \mathrm{kDa}$ and $33 \mathrm{kDa}$ could be either due to the proteins other than $\alpha$-keratose family or the fragments of $\alpha$-keratose proteins formed during the oxidation process as peracetic acid could cleave the peptide bonds.

\subsection{Characterization of the keratose nanostructures formed at low concentration}

Dynamic light scattering and atomic force microscopy were used to determine size and morphological characteristics of the structures formed at 5 and $10 \mathrm{mg} / \mathrm{ml}$ keratose solutions. Size distributions measured by DLS are given in Fig. 6. Hydrodynamic diameter values of the sample prepared at $5 \mathrm{mg} / \mathrm{ml}$ concentration ranged between $\sim 15 \mathrm{~nm}$ and $\sim 100 \mathrm{~nm}$ indicating high polydispersity of the sample. At $10 \mathrm{mg} / \mathrm{ml}$ concentration, lower end of the size distribution was observed to shift to $\sim 20 \mathrm{~nm}$. Other size distribution parameters of the two samples are summarized in Table 1.2D AFM image and particle size distribution of the sample at $5 \mathrm{mg} / \mathrm{ml}$ concentration are presented in Fig. 7. Particles having ellipsoidal cross section with sizes populated between $\sim 25$ and $\sim 75 \mathrm{~nm}$ were observed in consistent with the size measured using DLS. G-actin monomer with similar molecular weight $(\sim 42 \mathrm{kDa})$ as $\alpha$-keratin exhibited a hydrodynamic diameter of $5.8 \mathrm{~nm}$, quite lower than those obtained in current study [48]. Hydrodynamic diameter of a fibrous protein, fibrinogen ( $\mathrm{MW}=340 \mathrm{kDa}$ ) was determined to be $21.9 \mathrm{~nm}$ [49]. Comparing size and molecular weight distributions of the keratose with those of G-actin and fibrinogen and considering the DLS and AFM results, it can be concluded that the keratose proteins at low concentrations in aqueous solutions self-assembled into globular aggregates. Similar aggregation tendency was also obtained for keratin (reduced form) samples extracted from West Yorkshire region (UK) white sheep wool. Mean size (hydrodynamic diameter) of the keratin solution at $1 \mathrm{mg} / \mathrm{ml}$ concentration was found to increase from 14 to $30 \mathrm{~nm}$ as salt concentration increased from $5 \mathrm{mM}$ to $0.5 \mathrm{M}$. Cryo-TEM image of these samples indicated ellipsoidal structures with diameters between 12 and $44 \mathrm{~nm}$ at $5 \mathrm{mM}$ salt concentration [50].

\subsection{Characterization of the keratose hydrogels formed at high} concentration

Keratose solutions prepared at $10 \mathrm{w} \%$ concentrations formed selfstanding hydrogels upon incubation at $37{ }^{\circ} \mathrm{C}$ or $50{ }^{\circ} \mathrm{C}$ as given in Fig. S2. Cooling of the hydrogels to the room temperature did not change their integrity. Hence, rheological experiments of the hydrogels were performed at $25^{\circ} \mathrm{C}$, rather than their gelation temperatures. Strain sweep tests were carried out to determine linear viscoelastic region of the hydrogels [51]. The data obtained are presented in Fig. S3. Linear viscoelastic regions were observed between respective \% strain regions of $0.01-1.0$ and $0.01-0.1$ for the hydrogels prepared at $37{ }^{\circ} \mathrm{C}$ and $50{ }^{\circ} \mathrm{C}$. Using these results, frequency sweep experiments were carried out at $0.3 \%$ and $0.03 \%$ strain values for the hydrogels prepared at $37{ }^{\circ} \mathrm{C}$ and $50^{\circ} \mathrm{C}$, respectively to get the data within their linear viscoelastic regions. Plots of frequency dependence of moduli of the hydrogels are given in Figs. 8 and 9. For both samples, $G^{\prime}$ (storage modulus) values were obtained to be higher than $G^{\prime \prime}$ values (loss modulus) confirming their gel-like behavior. Plateau value of storage modulus was obtained as $0.17 \pm 0.03 \mathrm{kPa}$ for the hydrogel prepared at physiological temperature (Fig. 8). As gelation temperature increased to $50{ }^{\circ} \mathrm{C}$, the strength of the hydrogel increased to $3.7 \pm 0.5 \mathrm{kPa}$ as revealed by Fig. 9. Similarly, stronger chitosan based gels were also obtained upon increasing temperature and it was attributed to increase in hydrophobic attractions. Increasing temperature, on the other hand, decreases strength of hydrogen bonds. Although breaking hydrogen bonding seems unfavorable, it may provide chain flexibility to create contacts by facilitating the formation of network structure as suggested for chitosan hydrogels [52]. In another study, human hair derived keratose based hydrogels were prepared at $20 \mathrm{w} / \mathrm{v} \%$ concentration and $37^{\circ} \mathrm{C}$. Similar $\mathrm{G}^{\prime}$ value

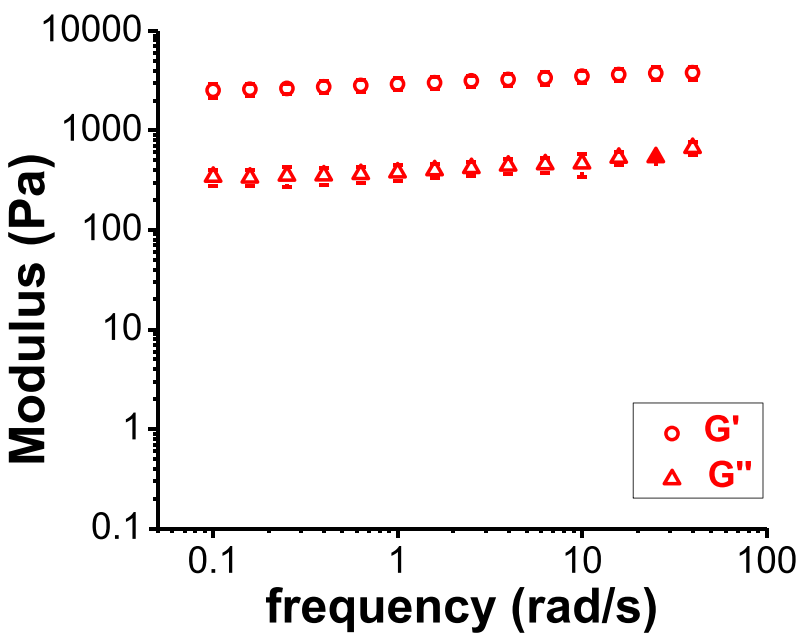

Fig. 9. Frequency sweep data of the hydrogel prepared at $50{ }^{\circ} \mathrm{C}$. 


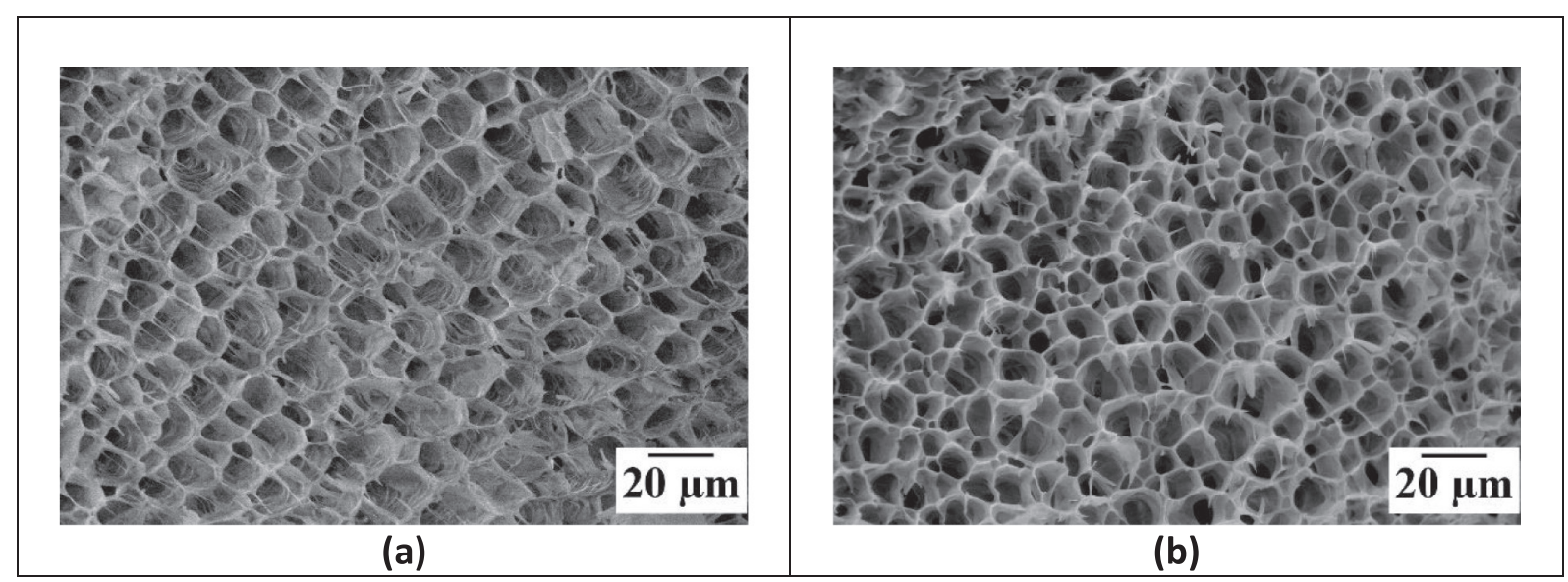

Fig. 10. SEM pictures of the freeze-dried keratose hydrogels prepared (a) at $37^{\circ} \mathrm{C}$ (b) $50{ }^{\circ} \mathrm{C}$.

$(\sim 0.21 \pm 0.09 \mathrm{kPa})$ was obtained for the hair-based keratose hydrogel at much higher concentration indicating that the source of keratinous proteins may affect the gelation properties of the resultant hydrogels [46].

Morphologies of the hydrogels prepared at $37^{\circ} \mathrm{C}$ and $50{ }^{\circ} \mathrm{C}$ observed using SEM are given in Fig. 10a and b, respectively. Cross-sections of the hydrogel prepared at physiological temperature indicated that the network was constituted mainly by association of the fibrils. Thicker and densely packed pore walls were observed in the structure of the hydrogel prepared at $50^{\circ} \mathrm{C}$. Mean pore sizes were obtained as $10 \pm 3 \mu \mathrm{m}$ and 9 $\pm 3 \mu \mathrm{m}$ for the samples gelled at $37^{\circ} \mathrm{C}$ and $50^{\circ} \mathrm{C}$, respectively. However, it was reported that hair-derived keratose at $20 \mathrm{w} / \mathrm{v} \%$ concentration had an average pore size of $13 \pm 1 \mu \mathrm{m}$ [46]. Higher pore size obtained at high keratose concentration can be due to stronger interactions between the keratose molecules. Pore size and architecture have direct effect on cell proliferation and migration and optimum pore size depends on the cell type. Considering optimum pore size suggested for the proliferation of fibroblast was suggested as $5-15 \mu \mathrm{m}$, keratose based hydrogels seemed suitable for the ingrowth of these kinds of cells [53].

Preliminary studies of hydrogel-cell interactions were conducted using CCK-8 assay. Cell proliferation results of the hydrogel prepared at $37{ }^{\circ} \mathrm{C}$ and the control sample, empty TCPS wells, are given in Fig. 11. Statistically significant difference between cell proliferation

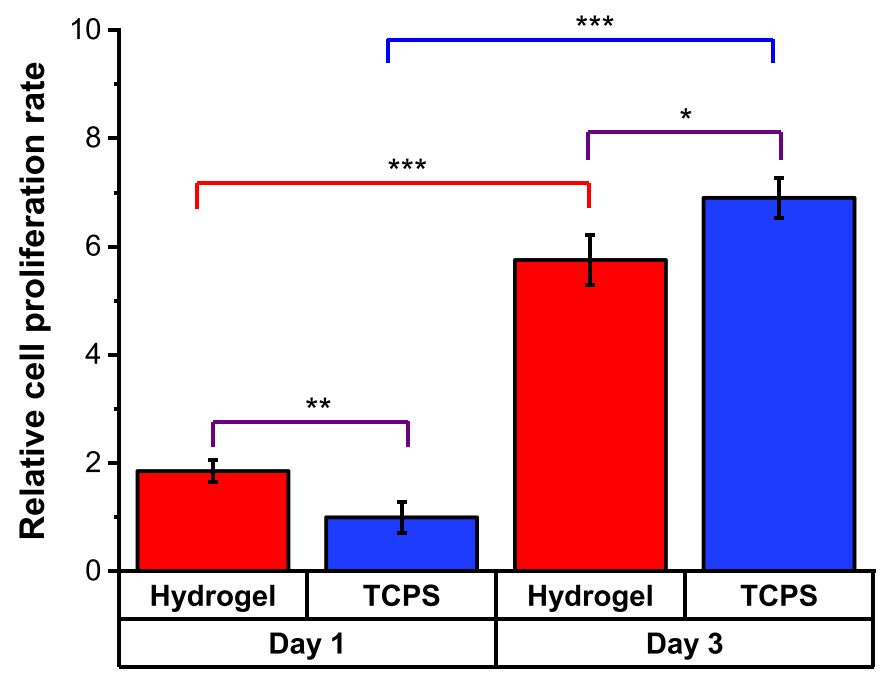

Fig. 11. Cell proliferation results of the hydrogel prepared at $37^{\circ} \mathrm{C}$ and empty TCPS wells obtained at the end of the 1st and 3rd day. $\left.{ }^{*} \rightarrow p=0.012 ;^{* *} \rightarrow p=0.005 ;{ }^{* * *} \rightarrow p=0\right)$. rates of both samples obtained at the end of day 1 and day 3 ( $p$ value $=0$ ) clearly indicated that the hydrogel and TCPS mediated cell proliferation. On the other hand, $p$ value of the cell proliferation rates of the hydrogel and TCPS obtained at the end of day 3 suggested that TCPS was slightly better support for extended cell culture periods. Nevertheless, superior performance of the TCPS was not unusual as TCPS was also found to accelerate cell proliferation with a higher rate compared to those of other hydrogels prepared using some self-assembled peptides [54,55], and hair-derived keratin [56].

\section{Conclusions}

Water soluble oxidized form of keratin proteins (or keratoses) was obtained from Akkaraman sheep wool with a quite high yield by using peracetic acid treatment. AFM observations and DLS measurements suggested that the keratose proteins at $5 \mathrm{mg} / \mathrm{ml}$ concentration in aqueous solutions self-assembled into globular nanoparticles with diameters populated between 15 and $100 \mathrm{~nm}$, which make them suitable for drug delivery applications. On the other hand, at $10 \mathrm{w} \%$ keratose concentration and upon incubation at $37^{\circ} \mathrm{C}$, self-supported interconnected hydrogel structure formed with an average pore size in the proposed range to support fibroblast ingrowth. As assembly temperature was increased from $37{ }^{\circ} \mathrm{C}$ to $50{ }^{\circ} \mathrm{C}$, the hydrogel network composed of denser walls with a minimal change in average pore size was obtained. In the preliminary cell culture experiments, the hydrogel prepared at $37^{\circ} \mathrm{C}$ was observed to support proliferation of $\mathrm{L} 929$ mouse fibroblasts cells. These results suggested that the keratose hydrogels could be promising candidates as scaffolds for soft tissue engineering with tunable viscoelastic and microstructure characteristics.

\section{Acknowledgments}

We thank to Lalahan Livestock Central Research Institute for kindly supplying wool samples and Materials Research Center at İzmir Institute of Technology for XRD, SEM and AFM experiments. İzmir Institute of Technology Biotechnology and Bioengineering Research and Application Center is acknowledged for DLS experiments. Prof. Muhsin Çiftçioğlu and Dr. Özlem Duvarcı are thanked for making oscillatory rheology experiments possible. Finally, we appreciate Dr. Sedef Tamburacı for her suggestions in cell studies.

\section{Appendix A. Supplementary data}

Supplementary data to this article can be found online at https://doi. org/10.1016/j.ijbiomac.2018.12.129. 


\section{References}

[1] A.Y. Gyurova, A. Michna, L. Nikolov, E. Mileva, Self-assembly of four-and twoantennary oligoglycines in aqueous medium, Colloids Surf. A Physicochem. Eng. Asp. 519 (2017) 106-116.

[2] R. Pugliese, F. Gelain, Peptidic biomaterials: from self-assembling to regenerative medicine, Trends Biotechnol. 35 (2016) 145-158.

[3] B. Kundu, M. Eltohamy, V. Yadavalli, R. Reis, H. Kim, Template mediated protein selfassembly as a valuable tool in regenerative therapy, Biomed. Mater. 13 (2018), 044101.

[4] T. Onur, E. Yuca, T.T. Olmez, U.O.S. Seker, Self-assembly of bacterial amyloid protein nanomaterials on solid surfaces, J. Colloid Interface Sci. 520 (2018) 145-154.

[5] M.L.P. Ramos, J.A. González, L. Fabian, C.J. Pérez, M.E. Villanueva, G.J. Copello, Sustainable and smart keratin hydrogel with $\mathrm{pH}$-sensitive swelling and enhanced mechanical properties, Mater. Sci. Eng. C 78 (2017) 619-626.

[6] W. Huang, S. Krishnaji, O.R. Tokareva, D. Kaplan, P. Cebe, Tunable crystallization, degradation, and self-assembly of recombinant protein block copolymers, Polymer 117 (2017) 107-116.

[7] P.C. Bessa, R. Machado, S. Nürnberger, D. Dopler, A. Banerjee, A.M. Cunha, J.C. Rodríguez-Cabello, H. Redl, M. van Griensven, R.L. Reis, Thermoresponsive selfassembled elastin-based nanoparticles for delivery of BMPs, J. Control. Release 142 (2010) 312-318

[8] J.D. Brodin, S.J. Smith, J.R. Carr, F.A. Tezcan, Designed, helical protein nanotubes with variable diameters from a single building block, J. Am. Chem. Soc. 137 (2015) 10468-10471.

[9] T. Lee, A. Cooper, R. Apkarian, V. Conticello, Thermo-reversible self-assembly of nanoparticles derived from elastin-mimetic polypeptides, Adv. Mater. 12 (2000) 1105-1110.

[10] C. Meier, M.E. Welland, Wet-spinning of amyloid protein nanofibers into multifunctional high-performance biofibers, Biomacromolecules 12 (2011) 3453-3459.

111] F.F. Miranda, K. Iwasaki, S. Akashi, K. Sumitomo, M. Kobayashi, I. Yamashita, J.R Tame, J.G. Heddle, A self-assembled protein nanotube with high aspect ratio, Small 5 (2009) 2077-2084.

[12] J.M. Smeenk, P. Schön, M.B. Otten, S. Speller, H.G. Stunnenberg, J.C. van Hest, Fibril formation by triblock copolymers of silklike $\beta$-sheet polypeptides and poly (ethylene glycol), Macromolecules 39 (2006) 2989-2997.

[13] W. Wang, Y. Chau, Self-assembled peptide nanorods as building blocks of fractal patterns, Soft Matter 5 (2009) 4893-4898.

[14] S. Zhang, Fabrication of novel biomaterials through molecular self-assembly, Nat. Biotechnol. 21 (2003) 1171-1178.

[15] Q. Zhou, J. Lin, F. Yuan, Z. Ye, F. Qiu, C. Tang, Y. Chen, X. Zhao, Self-assembly from low dimension to higher conformation of GGX motif in spider silk protein, Curr. Nanosci. 5 (2009) 457-464

[16] A.T. Neffe, C. Wischke, M. Racheva, A. Lendlein, Progress in biopolymer-based biomaterials and their application in controlled drug delivery, Expert Rev. Med. Devices 10 (2013) 813-833.

[17] M. Park, H.K. Shin, B.-S. Kim, M.J. Kim, I.S. Kim, B.Y. Park, H.Y. Kim, Effect of discarded keratin-based biocomposite hydrogels on the wound healing process in vivo, Mater. Sci. Eng. C 55 (2015) 88-94.

[18] M. Zoccola, A. Aluigi, C. Tonin, Characterisation of keratin biomass from butchery and wool industry wastes, J. Mol. Struct. 938 (2009) 35-40.

[19] A. Aluigi, A. Corbellini, F. Rombaldoni, M. Zoccola, M. Canetti, Morphological and structural investigation of wool-derived keratin nanofibres crosslinked by therma treatment, Int. J. Biol. Macromol. 57 (2013) 30-37.

[20] J. Zhang, Y. Li, J. Li, Z. Zhao, X. Liu, Z. Li, Y. Han, J. Hu, A. Chen, Isolation and characterization of biofunctional keratin particles extracted from wool wastes, Powde Technol. 246 (2013) 356-362.

[21] A. Tachibana, Y. Furuta, H. Takeshima, T. Tanabe, K. Yamauchi, Fabrication of wool keratin sponge scaffolds for long-term cell cultivation, J. Biotechnol. 93 (2002) 165-170.

[22] R.C. de Guzman, S.Y. Rabbany, PEG-immobilized keratin for protein drug sequestration and pH-mediated delivery, J. Drug Deliv. 2016 (2016)

[23] Q. Li, L. Zhu, R. Liu, D. Huang, X. Jin, N. Che, Z. Li, X. Qu, H. Kang, Y. Huang, Biologica stimuli responsive drug carriers based on keratin for triggerable drug delivery, J. Mater. Chem. 22 (2012) 19964-19973.

[24] P. Ramadoss, K.T. Arul, J.R. Ramya, M.R. Begam, V.S. Chandra, E. Manikandan, Enhanced mechanical strength and sustained drug release of gelatin/keratin scaffolds, Mater. Lett. 186 (2017) 109-112.

[25] M. Konop, D. Sulejczak, J. Czuwara, P. Kosson, A. Misicka, A.W. Lipkowski, L. Rudnicka, The role of allogenic keratin-derived dressing in wound healing in a mouse model, Wound Repair Regen. 25 (2017) 62-74.

[26] K.K. Nayak, P. Gupta, Study of the keratin-based therapeutic dermal patches for the delivery of bioactive molecules for wound treatment, Mater. Sci. Eng. C 77 (2017) 1088-1097.

[27] J. Wang, S. Hao, T. Luo, Z. Cheng, W. Li, F. Gao, T. Guo, Y. Gong, B. Wang, Feather keratin hydrogel for wound repair: preparation, healing effect and biocompatibility evaluation, Colloids Surf. B: Biointerfaces 149 (2017) 341-350.
[28] J.S. Li, Y. Li, X. Liu, J. Zhang, Y. Zhang, Strategy to introduce an hydroxyapatitekeratin nanocomposite into a fibrous membrane for bone tissue engineering, J. Mater. Chem. B 1 (2013) 432-437.

[29] S. Saravanan, D. Sameera, A. Moorthi, N. Selvamurugan, Chitosan scaffolds containing chicken feather keratin nanoparticles for bone tissue engineering, Int. J. Biol. Macromol. 62 (2013) 481-486.

[30] H. Zhang, J. Liu, Electrospun poly (lactic-co-glycolic acid)/wool keratin fibrous composite scaffolds potential for bone tissue engineering applications, J. Bioact. Compat. Polym. 28 (2013) 141-153.

[31] L. Sando, M. Kim, M.L. Colgrave, J.A. Ramshaw, J.A. Werkmeister, C.M. Elvin, Photochemical crosslinking of soluble wool keratins produces a mechanically stable biomaterial that supports cell adhesion and proliferation, J. Biomed. Mater. Res. A 95 (2010) 901-911.

[32] K. Yamauchi, M. Maniwa, T. Mori, Cultivation of fibroblast cells on keratin-coated substrata, J. Biomater. Sci. Polym. Ed. 9 (1998) 259-270.

[33] T.R. Ham, R.T. Lee, S. Han, S. Haque, Y. Vodovotz, J. Gu, L.R. Burnett, S. Tomblyn, J.M. Saul, Tunable keratin hydrogels for controlled erosion and growth factor delivery, Biomacromolecules 17 (2015) 225-236.

[34] P. Sierpinski, J. Garrett, J. Ma, P. Apel, D. Klorig, T. Smith, L.A. Koman, A. Atala, M. Van Dyke, The use of keratin biomaterials derived from human hair for the promotion of rapid regeneration of peripheral nerves, Biomaterials 29 (2008) 118-128.

[35] H. Yalçın, M.A. Kaya, Comparative geometrical morphometry on the skull bones of Anatolian wild sheep and Akkaraman sheep, Atatürk Üniversitesi Vet. Bil. Derg. 4 (2009) 105-116.

[36] C.A. Schneider, W.S. Rasband, K.W. Eliceiri, NIH image to Image J: 25 years of image analysis, Nat. Methods 9 (2012) 671-675.

[37] H. Xie, S. Li, S. Zhang, Ionic liquids as novel solvents for the dissolution and blending of wool keratin fibers, Green Chem. 7 (2005) 606-608.

[38] K. Wang, R. Li, J. Ma, Y. Jian, J. Che, Extracting keratin from wool by using L-cysteine, Green Chem. 18 (2016) 476-481.

[39] D.R. Rao, V. Gupta, Crystallite orientation in wool fibers, J. Appl. Polym. Sci. 46 (1992) 1109-1112.

[40] J. Kong, S. Yu, Fourier transform infrared spectroscopic analysis of protein secondary structures, Acta Biochim. Biophys. Sin. 39 (2007) 549-559.

[41] S. Hiilterhaus-Bong, H. Zahn, Contributions to the chemistry of human hair. 1. Analyses of cystine, cysteine and cystine oxides in untreated human hair, Int. J. Cosmet. Sci. 9 (1987) 101-110.

[42] J.M. Cardamone, A. Nuñ, R.A. Garcia, M. Aldema-Ramos, Characterizing wool keratin, Adv. Mater. Sci. Eng. 2009 (2009).

[43] N. Eslahi, F. Dadashian, N.H. Nejad, An investigation on keratin extraction from wool and feather waste by enzymatic hydrolysis, Prep. Biochem. Biotechnol. 43 (2013) 624-648.

[44] P. Kakkar, B. Madhan, G. Shanmugam, Extraction and characterization of keratin from bovine hoof: a potential material for biomedical applications, Springerplus 3 (2014) 596.

[45] D.M. Byler, H. Susi, Examination of the secondary structure of proteins by deconvolved FTIR spectra, Biopolymers 25 (1986) 469-487.

[46] R.C. de Guzman, M.R. Merrill, J.R. Richter, R.I. Hamzi, O.K. Greengauz-Roberts, M.E. Van Dyke, Mechanical and biological properties of keratose biomaterials, Biomaterials 32 (2011) 8205-8217.

[47] D. Rama Rao, V. Gupta, Thermal characteristics of wool fibers, J. Macromol. Sci. Part B Phys. 31 (1992) 149-162.

[48] N. Kanzaki, T.Q. Uyeda, K. Onuma, Intermolecular interaction of actin revealed by a dynamic light scattering technique, J. Phys. Chem. B 110 (2006) 2881-2887.

[49] J. Armstrong, R. Wenby, H. Meiselman, T. Fisher, The hydrodynamic radii of macromolecules and their effect on red blood cell aggregation, Biophys. J. 87 (2004) 4259-4270.

[50] Z. Lu, F. Pan, D. Wang, M. Campana, H. Xu, I.M. Tucker, J.T. Petkov, J. Webster, J.R. Lu, Unusual surface and solution behaviour of keratin polypeptides, RSC Adv. 6 (2016) 105192-105201.

[51] J.M. Zuidema, C.J. Rivet, R.J. Gilbert, F.A. Morrison, A protocol for rheological characterization of hydrogels for tissue engineering strategies, J Biomed Mater Res B Appl Biomater 102 (2014) 1063-1073.

[52] J. Cho, M.C. Heuzey, A. Bégin, P.J. Carreau, Physical gelation of chitosan in the presence of $\beta$-glycerophosphate: the effect of temperature, Biomacromolecules 6 (2005) 3267-3275.

[53] N. Annabi, J.W. Nichol, X. Zhong, C. Ji, S. Koshy, A. Khademhosseini, F. Dehghani, Controlling the porosity and microarchitecture of hydrogels for tissue engineering, Tissue Eng. B Rev. 16 (2010) 371-383.

[54] A. Mujeeb, A.F. Miller, A. Saiani, J.E. Gough, Self-assembled octapeptide scaffolds for in vitro chondrocyte culture, Acta Biomater. 9 (2013) 4609-4617.

[55] A. Nagayasu, H. Yokoi, J.A. Minaguchi, Y.Z. Hosaka, H. Ueda, K. Takehana, Efficacy of self-assembled hydrogels composed of positively or negatively charged peptides as scaffolds for cell culture, J. Biomater. Appl. 26 (2012) 651-665.

[56] S. Wang, F. Taraballi, L.P. Tan, K.W. Ng, Human keratin hydrogels support fibroblast attachment and proliferation in vitro, Cell Tissue Res. 347 (2012) 795-802. 